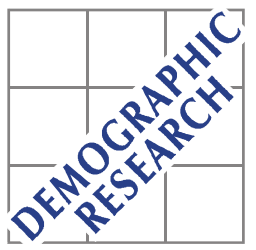

Demographic Research a free, expedited, online journal

of peer-reviewed research and commentary in the population sciences published by the Max Planck Institute for Demographic Research

Konrad-Zuse Str. 1, D-18057 Rostock · GERMANY

www.demographic-research.org

DEMOGRAPHIC RESEARCH

VOLUME 17 ARTICLE 15, PAGES 441-464

PUBLISHED 04 DECEMBER 2007

http://www.demographic-research.org/Volumes/Vol17/15/

DOI: 10.4054/DemRes.2007.17.15

Reflexion

\title{
Social mobility and fertility
}

\section{Gianpiero Dalla Zuanna}

This open-access work is published under the terms of the Creative Commons Attribution NonCommercial License 2.0 Germany, which permits use, reproduction \& distribution in any medium for non-commercial purposes, provided the original author(s) and source are given credit. See http:// creativecommons.org/licenses/by-nc/2.0/de/

(C) 2007 Dalla Zuanna 


\section{Table of Contents}

1 Introduction $\quad 442$

$2 \quad$ Fertility and intra-generational mobility: do personal well- 443

being aspirations drive fertility choices?

$2.1 \quad$ Contrasting pre-transitional and transitional periods 443

$2.2 \quad$ Post-transitional period: women's careers, preferences, and 445 personal well-being

3 Fertility and inter-generational mobility. Does "status anxiety" 448

for children drive fertility choices?

3.1 Contrasting pre-transitional and transitional periods 448

3.2 Lowest-low fertility contexts: the persistence of status anxiety 452

for children in explanations of fertility behaviour

$3.3 \quad$ The dilution effect 454

3.4 An evolutionary viewpoint 455

4 Conclusions 456

$5 \quad$ Acknowledgements $\quad 459$

$\begin{array}{ll}\text { References } & 460\end{array}$ 


\title{
Social mobility and fertility
}

\author{
Gianpiero Dalla Zuanna ${ }^{1}$
}

\begin{abstract}
Intra- and inter-generational social mobility have in the past played an important role in attempts to explain fertility behaviour, and continue to do so today. The opinions expressed by social scientists in the first part of the 20th century are renewed and confirmed. More specifically: (1) intra-generational social mobility has been reinforced by the personal well-being aspirations and job careers of women; (2) status anxiety parents feel for their children pushes fertility down in large areas of the developed world (mainly in southern European and eastern Asian countries). Therefore, the provocative idea of Ariès that in the rich world, the child-king has now been replaced by the couple-queen does not perfectly hold.
\end{abstract}

${ }^{1}$ University of Padua. E-mail: gpdz@stat.unipd.it 


\section{Introduction}

When fertility began to fall in the now developed countries, some social scientists noted a connection between upward "social mobility" (henceforth "mobility") and low fertility. In developing his theory of social capillarity, Dumont wrote in 1890:

Any man tends ... to climb unceasingly, as oil rises in a lamp wick... For one who starts at the bottom to arrive at the top, it is necessary to run fast and not to be encumbered with baggage. Thus, while an ambitious man can be served by a good marriage... his own children, particularly if they are numerous, almost inevitably slow him down (quoted by Greenhalgh, 1988, p. 630-631).

This idea of "competition" between one's own children and upward mobility is key to explaining fertility transition. However, it is only one of many possible links between mobility and fertility. More than one population issue should be taken into account. The problem may be divided into two topics: (1) Fertility and intragenerational mobility; (2) Fertility and inter-generational mobility.

In reference to the first point, the concept of intra-generational social mobility (i.e. when an individual rises from one social class to another during her/his adult life) will be extended to include the personal well-being aspirations of the parents (i.e. when parents limit their fertility in an effort to improve their living conditions).

In reference to the second point, the idea of inter-generational mobility (i.e. when children belong to a different social class than that of their parents) will also be extended to include parents' aspirations of having high quality children. We do not take into consideration another aspect, or that of the impact of inter-generational mobility on the fertility of the children themselves. The study of this topic, by authors such as Bresard (1950); Girard (1951); Berent (1952); Westoff (1953, 1981); Westoff et al. (1961, 1963) and Zimmer (1981) has produced rather controversial results.

Demographic literature is herein examined, in order to re-consider from this particular point of view several explanations for both fertility behaviour (not only fertility decline) and low fertility, in developed and developing countries. This investigation also provides the opportunity to speculate on the future of post-transitional fertility patterns. 


\section{Fertility and intra-generational mobility: do personal well-being aspirations drive fertility choices?}

\subsection{Contrasting pre-transitional and transitional periods}

According to Dumont's idea of social capillarity, in a modern society, the smaller the size of one's family, the higher one's social climbing opportunities. This idea lies at the core of Davis' (1963) interpretation of transitional fertility decline, as well as other authors who wrote during the birth depression of the 1930s, such as Lorimer and Osborn (1934, pp. 325-327) and particularly, Carr-Saunders (1936, ch. XVII). Their explanation of fertility transition may be convincing, as the notion of a close relationship between modernisation and fertility decline, emphasised by almost all of the fathers of the demographic transition theory, is best explained in terms of individual strategies. According to Davis, during and after the Industrial Revolution, three main social changes were in contrast to fertility: (1) the new industrial world gave most people new upward possibilities, not previously available in traditional peasant societies; (2) the decline in infant mortality meant an increase in the number of surviving children; (3) parents no longer controlled their children's revenues, as families lost their traditional function (see also Davis, 1937, for an apocalyptic vision of this last point). Consequently, in order to maximise their own opportunities, people had to reduce the "family strains" induced by modernisation and change their demographic behaviour. There exist different possibilities for bringing about change, depending on the particular historical moment (the reason why Davis' formulation is called the "multiphasic transitional theory"). Individuals may emigrate, change marriage habits (the Malthusian, traditional "demographic answers" to coping with population growth preventively), or reduce their marital fertility. Commenting the article of Davis, Glass (1965) states that the main mechanism of change is the possibility of intra-generational mobility, since decline in infant mortality and parental control over children cannot induce demographic changes if social climbing opportunities do not work effectively. When this happens, according to Glass, "a conflict between levels of living and aspirations" triggers new demographic behaviour (p. 18).

The positions of Davis and Glass have been enriched by years of population research which has attempted to explain fertility transition in a variety of ways. However, the notion that a contrast exists between upward mobility and high fertility is usually only implicitly affirmed. For example, the often quoted idea expressed by Coale (1973), concerning the necessity of a "rational calculus" to control marital fertility, assumes that, in a context of ongoing modernisation it is "rational," i.e., "convenient," for parents to reduce the number of children they have. In a competitive market 
economy, this "convenience" corresponds to the maximisation of opportunities relative to one's own upward mobility.

This opposition between the "irrational fertility" of peasant society and the "rational fertility" of the changing and changed world is not shared by Caldwell (1982, 2005). According to Caldwell, there is continuity in economic rationality before and after the fertility transition and maximisation of one's own possibilities for upward mobility or - at least - social security. Parents reduce marital fertility when, due to changes exogenous to the couple, intergenerational wealth flows are modified (before transition: from children to parents; during and after transition: from parents to children). Radicalising Caldwell's viewpoint, offspring are instrumental tools in the hands of parents, who pursue their own interests.

Other authors have strongly criticised the idea of a difference in rationality between past and present fertility choices (see Mason, 1997, pp. 447-448, for an extensive review). However, these critics do not oppose the idea that aspiring to one's own upward mobility could also have driven fertility choices in the past. Rather, they simply extend the concept, suggesting that couples in traditional societies also try to climb the social ladder (or at least maintain their social position) by managing their fertility. In order to achieve this aim, when infant mortality was high, and parents' control over children was significantly strong, it was "rational" to have many children and/or to use other "demographic responses" (such post-natal control - infanticide or other) to reduce the number of children to look after. Fertility choices depend on social organisation and contextual circumstances (i.e. economic situation, social class, episodic crises, and so on).

However, this sort of "Olympic economic rationality" shared by all couples throughout history is not fully convincing. In many situations

The absence of family size limitation does not necessarily imply that children represent a net economic return to parents [the case of England during the Industrial Revolution is enlightening]. The evidence for contemporary societies is conflicting, but the assumption of a high demand for children in these settings is certainly unjustified (Cleland and Wilson, 1987, p. 17).

This position is also shared by other authors who have empirically shown that - for pre-transitional couples - having a child is not economically convenient, especially in the brief and medium term (Lindert, 1980, see especially pp. 41-49; Smith, 1984). 


\subsection{Post-transitional period: women's careers, preferences, and personal well- being}

If we assert that rationality drives both pre- and post-transitional fertility behaviour, the idea of rationality itself should be extended, considering that a couple wishes to maximise all values, not only material ones. As shown below, this last idea has been applied extensively by the theorists of the second demographic transition in reference to the developed world during the second half of the $20^{\text {th }}$ century.

The notion that there exists a contrast between fertility and one's own mobility has been revisited over the last few years, spurred by the increasing proportion of women working in the labour market. Having a child may increase the risk that a woman will decide to give up her job, or stop or delay her career. According to some authors, the "irruption" of women into the labour market and their desire to pursue careers provide a key to understanding renewed fertility decline in the developed world over the last 30 years, after the post-war baby-boom. The negative influence on fertility for women who pursue careers may be particularly great when public and private institutions (mainly welfare systems and couples) are not able to reconcile the time women spend on production and reproduction. This has occurred in the lowest-low fertility cases of southern Europe, German-speaking countries, and eastern Asian countries (see McDonald, 2000 for a theoretical approach; Caldwell and Schindlmayr, 2003 for an extensive review; Hoem, 2005 for an analysis of lowest-low German fertility; EspingAndersen et al., 2007 for some empirical results concerning Spain and Denmark). According to this theory, and in reference to the highly industrialised developed countries, the negative pressure of women's careers on fertility is only a new version of the already mentioned contrast between the "industrial world" and the family. Settled agricultural activity - based on the family unit - has been replaced by industrial production, which does not fundamentally depend on the family (Caldwell, 2004, reechoing Davis, 1937).

The substantial continuity expressed in the above theory is not shared by theorists of the second demographic transition - SDT (see, e.g., van de Kaa, 2001, 2004). The SDT, which deals primarily with the post-modern rich world, (even if developing countries may soon be "contaminated"), argues for the usefulness of defining a new transition, given that the motivations for reducing fertility have changed radically during the last 30-40 years compared with the previous century. This seminal idea is expressed by Ariès (1980, p. 650):

Couples - and individuals - no longer plan life in terms of the child and his personal future, as was the case during the nineteenth and early twentieth centuries. This does not mean that the child has disappeared from such plans but that he fits into them as one of the various components that make it possible for adults to blossom as 
individuals. His existence, therefore, is related to plans for a future in which he is no longer the essential variable, as he was during the nineteenth century.

According to Ariès, the first fertility transition was driven by the ideology of the "child-king," that is, parents tried to favour the upward mobility of their children (see part three of this note). Instead, fertility nowadays is driven by the ideology of the "couple-queen," or individual-queen/(king). Provocatively, Ariès considers this ideology to be a return to the Middle-Ages, when affectivity was not centred on the family and children.

In post-modern society, the "existence" of children is due to the possibility of their becoming a post-modern value, i.e., conducive to the self-realisation of their parents. According to van de Kaa (2004, p. 77), before deciding whether or not to have a child, post-modern women ask themselves:

Will my life, and the relationship with my partner, be enriched if I interrupt contraception and use my basic right to have a child, or an additional child now?

Hakim's (2003) preference theory emphasises, and better specifies the SDT hypothesis of fertility decline. She shows that, if one's own "pure" preferences drive fertility choices, a relevant proportion (10-20\%) of women now living in the Western world would follow career goals, renouncing motherhood, whereas a similar proportion would be happy to have more children, renouncing their jobs. Most women are necessarily adaptive, their jobs and reproductive choices depending on external circumstances (mainly economic burdens, family troubles, and the welfare system). Several empirical results show that as time passes, groups of women characterized by specific preferences emerge; these groups become particularly well-defined during a woman's teens. However, it is not clear how preference patterns emerge during infancy and adolescence (Hakim, 2000, pp. 185-189). Other authors suggest that preferences are written into our genes, and that this genetic drive surfaces in post-materialistic societies, where material constraints on individual fertility preferences are weakening (Udry, 1994; Kohler et al., 1999; Kohler and Rodgers, 2003).

In reference to the SDT, Hakim states that, in the post-modern world, individuals' preferences have increasing influence over fertility and women's own mobility. This is because for the first time in history - thanks to the contraceptive revolution and the ideational "silent revolution" (Inglehart, 1977) - women control their own fertility choices. Empirical results, using both longitudinal and cross-sectional surveys, show that in the UK and USA, preferences arising at an early age influence fertility and family-oriented women have twice as many children as work-oriented women. Of course, real choices are obviously not determined by preferences alone, but also by 
contextual circumstances. The strength of the statistical association between "preferences" and fertility does not noticeably change if other variables (i.e. education, social class, etc.) are taken into account.

Kohler et al. (2005) have recently developed another approach which concerns the preferences of parents. They link personal psychological "well-being" (measured by means of a direct question) with the number of children (see also the above authors for an extensive review on this topic). The authors use data from a panel of Danish monozygotic twins interviewed at the beginning of the $21^{\text {st }}$ century, and thus are able to control for genetic and educational endowments, and to emphasise the "pure" effect of childbearing on happiness. The main result of their study is that the first child increases the happiness of both parents, whereas more children do not add to the happiness of fathers and diminishes the happiness of mothers, especially if they are young. These results - although conditioned by the fact that they are limited to the Danish social context - suggest that, in the rich world:

Women's and couples' motivations to have additional children may be less robust with respect to changes in the costs and benefits of children than their motivation to have at least one child. Desires for second and higher-order children may thus respond strongly to altered socioeconomic conditions, family policies, social norms, or ideational context... Our analysis does not suggest that the individual motivation in terms of well-being for second and third children is sufficiently strong to result in a fertility level close to replacement level (Kohler et al., 2005, p. 436).

The contrast between the traditional vision of fertility behaviour and that of the SDT in determining the "primary cause" of persistent low fertility in rich countries is profound: the former emphasises "long-term" economic changes, while the latter stresses the importance of a post-modern ideological revolution. However, in spite of their divergences with regard to the "main driving cause" behind low fertility, the two visions share the same basic idea that the goal of maximising one's own situation influences the choice of having a child in contemporary rich countries. The concepts of "self-realization," "preferences" and "well-being" may be considered post-materialistic versions of similar concepts such as "intra-generational mobility" and "careers". Neither the proponents of the traditional vision nor the SDT theorists explicitly take into account the desire for upward mobility and well-being of one's own child as a possible force driving fertility decisions in the post-modern world. 


\section{Fertility and inter-generational mobility. Does "status anxiety" for children drive fertility choices?}

\subsection{Contrasting pre-transitional and transitional periods}

In 1890, when Dumont defined social capillarity, he stated that a small family is brought about not only by the desire for a career, but also by the aspiration of parents to guarantee their children a better social position (see the quotation of Dumont by Ariès, 1980, p. 647). Social researchers in the first half of the $20^{\text {th }}$ century generally shared this view. They enriched the idea of an opposition between the social climbing of children and their parents with the notion of a contrast between fertility decisions and the possibility for upward mobility of children already born, in a context of growing competition between families (emphasis in italics added):

[Marital fertility drops] because of the awakened ambition of the individual (...) [and] because parents are solicitous not only to maintain, but to raise, the social and economic position of their children (Taussig, 1911, Ch. 53, quoted by McNicoll, 2001, p. 131).

It is quite generally recognised that most people who have a good social and economic status are highly desirous of maintaining it and will strive hard to prepare their children to maintain a similar status. Likewise, as freedom of thought increases, many people who have less desirable positions will revolt against their lowly status and will try hard to improve it and to enable their children to enjoy the benefits of a better status even though they themselves cannot achieve it. If we call this urge to maintain or secure a good social status "ambition", then we may say that ambition is one of the most important of all factors leading to the voluntary control of family size of the

family. (...) "It requires little argument to convince anyone that the great majority of couples with a good social and economic status will much more easily prevent the loss of the status or maintain it and ensure somewhat the same status to their children if families are relatively small. This is even more true of couples that are themselves trying to rise in social position and to ensure an improved status to their children (Thompson and Lewis, 1964, $5^{\text {th }}$ edition, pp. 320-321). These concepts were similarly expressed, albeit in different words, in the previous editions - the first printed in 1930).

As a motive for keeping the size of family small, the fear of unemployment is probably far less important than the ambitions of parents for their children (...). There is a powerful incentive to limit the size of the family in the interests of the children (...). [To increase fertility] it is necessary to ensure that the member of the three or four 
child family is not handicapped in the race on account of lack of equipment, as compared with the member of the one or two child family" (...). In part the low fertility of the higher income classes is due to the possibility of what amounts to the purchase of positions for children; for the fewer the children, the more money there is for expenditure in this direction" (Carr-Saunders, 1936, chapter XVII entitled: 'The small family problem').

The higher the status of the family, the more costly it is to place the children in one's own or in a higher occupation (Davis, 1937 - 1997, p. 621).

When discussing fertility decline, the classic authors of the demographic transition commonly shared this double negative association between low fertility and the mobility of parents (intra-generational) and children (inter-generational). These two new possibilities for social climbing meant new burdens for couples who in turn reduced their fertility in order to "promote the health, education, and material welfare of the individual child" (Notestein, 1945, pp. 37-57). The family is seen as a competitive unit, which tries to maximise the well-being of all its members:

In addition to all these facets of the subject, there is another, this emphasized by Dumont, namely, that small families may be motivated by the desire of parents to provide better opportunities for the advancement of their children rather than by their own mobility ambitions (Westoff, 1953, p. 33).

If each family is concerned with its prospective standing in comparison to other families within its reference group, we can understand why the peoples of the industrialising and hence prospering countries altered their demographic behaviour (Davis, 1963, p. 362).

This double pressure on parents is also taken into account by Becker (1981, p. 12), in his discussion concerning the possibility (or better, the rationality) of combining "altruism in the family and selfishness in the market place". He adopts an evolutionary point of view, considered below.

Altruistic parents might not to have more children than selfish parents [i.e. parents not altruistic towards their children], but they invest more in the human capital or quality of children because the utility of altruistic parents is raised by investment returns that accrue to their children (...). Consequently, children from altruistic families tend to be more "successful" than children from selfish families, which expands the influence of altruistic families beyond their numbers. Moreover, their 
influence might grow over time because successful parents tend to have successful children, and altruism towards children is also likely to be passed on from one generation to the next.

Lastly, Ariès (1980, pp. 646-647) expressed the most radical position:

During this period [i.e., since the late $18^{\text {th }}$ century in France and the early $19^{\text {th }}$ century in the rest of Western Europe] Western society was shaken by a veritable revolution in sensibility, a revolution as important as the French Revolution or the Industrial Revolution. Affectivity became centered about the family and the children. (...) It turned inward upon itself and organised itself in terms of the children and their future. (...) This sort of planning implied the desire to ensure that the children's economic and social status would be superior to that of their parents. Thus, birth control was linked with social mobility. (...) To my mind, seeing that one's children got ahead in a climate of social mobility was the deep motivation behind birth control.

These outcomes have been enriched by several studies, mainly with regard to societies characterised by strong ties between parents and children, in both pretransitional populations as well as contemporary realities. Two important contributions made toward understanding the past include Johansson's (1987a) work on European élites and Greenhalgh's (1988) research on traditional peasant China.

Sharing the viewpoint of Ariès, Johansson shows that the control of early marital fertility by continental European élites was determined by the ideational egalitarian movement born in Europe during the Modern Era and which triumphed during the $19^{\text {th }}$ and $20^{\text {th }}$ centuries (Flandrin, 1976; Johansson, 1987b). This ideology stresses the concept that all couples' children should have the same rights. Before this "egalitarian revolution," in order to maintain the status of the family and the family patrimony, the strategy was to concentrate parental resources and the possibilities of marriage on the first son and only one daughter. Among a number of European élites after the "egalitarian revolution" - long before the drop in infant mortality - all children had the right to marry and to inherit their parents' patrimony. Consequently, couples had to reduce their fertility in order to reduce the number of potential heirs, thus saving social status and family patrimony. A comparison of pre- and post-revolutionary periods reveals that the aim of parents is the same (to maintain or improve family status), but that the micro-demographic strategy changes in order to fit the new ideational context. Ten years later, Johansson does not seem to adhere to Ariès's idea of changing motivations for fertility declines during the second half of the $20^{\text {th }}$ century (see part one of this note). Referring to the low fertility of contemporary populations, he echoes the views of American demographers of the 1930s: 
In socioeconomic terms the problem of demographic contraction could be framed as a natural consequence of socially constructed status anxiety. (...) In the twentieth century, people living in the developed countries (European or not) play the same role vis-à-vis the rest of the world as Europe's materially privileged elites once did vis-à-vis Europe as a whole. At present the majority of any developed country's population is "middle class", meaning that most families are composed of status-anxious husbands and wives, who have small families (the two children norm) in order to maintain high standard of living for themselves, while avoiding downward mobility for the children (Johansson, 1997, p. 632).

This idea of "status anxiety" is not only highly evocative but recalls Greenhalgh's (1988) research on fertility in China during the pre- and post-transitional eras. The author describes a similar dynamic in a paper concisely entitled: "Fertility is mobility". According to Greenhalgh, both during past centuries and today, one might think of Chinese society as made up of sets of families competing for security and upward mobility. Compared to other pre-transitional contexts, within late-traditional Chinese society (during the Qing Dynasty: 1644-1911) there was an extraordinary degree of mobility: poor (male) children were also able to climb the social ladder by means of education (the cost of which was relatively low in Imperial China). The submission of children to parents, attitudes of gender inequality towards daughters, and lack of egalitarian rules among siblings allowed parents to manage family resources (i.e. the work activities of their sons and the position of their daughters in the marriage market). Some sons and daughters worked hard in order to permit one (or more) male siblings to pursue upward mobility by means of education. Consequently, the more children a family had, the greater the possibility of upward mobility for the entire unit or, at least, of maximum social security for parents and children.

In looking at the rapid decline of fertility in China during the 1970s and 1980s, Greenhalgh illustrates three different processes which reduced fertility in Taiwan, rural mainland, and urban China. She suggests that the basic structure of the Chinese family has not changed. China continues to be characterized by sets of families who compete for security and upward mobility, and parents who invest all of their resources in improving the social level of the family (by means of upward mobility of one or more children). However, environmental conditions have changed drastically, and children's upward mobility may be better pursued when there are just one or two children, mainly due to the cost of education which has drastically risen. Moreover:

The reason fertility declined so rapidly is that Chinese families in all [three] institutional settings responded to these institutional [i.e., exogenous] changes by 
applying and acting on traditional (economic) or modified-traditional (political-cumeconomic) cost-benefit analyses of how best to secure and advance their interests in these changed environments (Greenhalgh, 1988, p. 667).

\subsection{Lowest-low fertility contexts: the persistence of status anxiety for children in explanations of fertility behaviour}

The persistence over time of strong family ties may also be useful in explaining lowestlow fertility in Italy and Spain over the last 25 years (see Caldwell and Schindlmayr, 2003, pp. 248-250 for a review; see also Bettio and Villa, 1998; Dalla Zuanna, 2001, 2004; Dalla Zuanna and Micheli, 2004). A title of a recent paper by Livi Bacci (2001) summarises the issue well: "Too few children and too much family". The importance of family blood ties for those living on the northern shores of the Mediterranean Sea has long been different than for those living in central or northern Europe. This is a fundamental anthropological difference, which has differentiated these populations for centuries (Reher, 1998; Micheli, 2000).

Authors who support this view are not suggesting that family is more important in southern Europe than elsewhere: family remains important everywhere and the notion that a close connection exists between modernisation and a weakening family remains debateable. However, in southern European countries, the ties between parents and children were and still are very strong, even after individuals are no longer in their twenties, whereas this was and is not the case in northern Europe and in overseas English-speaking countries. In northern Europe, during the Late Middle and Modern Ages, the "circulation of servants" was very common - that is, the habit of "exchanging" children, who went to other homes to learn a trade. In southern Europe, this did not happen as frequently, as young people only went to work and live at their master's residence if they were driven by severe economic need (Reher, 1998). Consequently, young people in southern Europe did not leave home as early as in northern Europe. Although the fading of rural society brought about much change, the distinction between societies with strong or weak family ties is still present. With regard to Italy, the physical proximity over time between children and parents has actually increased: young adults not only leave the home later but when they do depart, they often end up residing nearby. Furthermore, visits between parents and children occur very frequently (Dalla Zuanna, 2001). The physical proximity of new couples to their families is also extraordinarily constant over time. For marriages celebrated in Italy over the last 30 years of the previous century, only $30 \%$ of new couples settled farther than one kilometre away from at least one set of parents, and one in four couples settled less than one kilometre from both sets of parents. 
This persistent proximity between parents and children has gone hand in hand with intense exchanges of both inter and intra-generational nature. Southern European parents feel responsible in toto for building the human capital of their children, such that the upward mobility and quality of life of their children takes on value laden meanings pertinent to their very own existence. From this perspective, their exasperating "Malthusian prudence" is easy to understand. Not having a second or third child is due both to the fear of lowering the quality of life of the existing child (or children) and of not being able to guarantee sufficient resources for a new child. Hence, Italians have fewer children because they "love them too much" and not the other way around (Palomba, 1995), and because of they generally feel a heavy burden of responsibility for the future of their children (Schneider and Schneider, 1996).

Aspiring for one's own children's mobility is a powerful fertility reducing mechanism in other contexts as well. Commenting on an article by Casterline (2001), Haaga (2001, p. 55) states that:

As Casterline points out, a great deal of literature suggests that aspirations anxieties might be a better term - for the education of one's children are connected to fertility decisions. (...) [Everywhere], once education is established as the principal determinant of status, of economic and social mobility, the rules of the [fertility] game have changed.

However, a few lines later Haaga laments that:

It is unfortunate how little direct evidence demographers usually have, or even seek, of what Casterline terms the mediating cognitive factors, i.e. factors that might connect aspirations and fertility behaviours.

An important exception to this dearth of research, also quoted by Haaga, is exemplified by Knodel et al's (1990) research on Thailand's transitional fertility decline. The authors found clear-cut evidence of a causal mechanism linking the desire for children's schooling and mobility, and family size limitation. Cleland and Wilson (1987, p. 22) have also highlighted similar results, in reference to the World Fertility Surveys collected in the developing world during the 1970s:

Aspirations for education of children are often found to be negatively correlated with overall family size desires. 


\subsection{The dilution effect}

If we do not address the decisional processes affecting fertility choices, and look only at the influences of offspring number on the social mobility of children, the results are clear. As Blake (1989, p. 306) stated:

[There is]... overwhelming evidence concerning the undesirability of large families for the children involved and, ultimately, for the educational quality of the society in question.

Dealing with extensive post-World War II U.S. data, Blake finds that the smaller the family size, the higher the "quality" of children, particularly - although not always from an educational standpoint (see chapter 9 of above volume, and Blake, 1985, for an exhaustive summary of the main results). This regularity holds when measured for multiple cohorts and after controlling for several possible confounding variables, such as the parents' social class. These results are more evident for the highest parities although clear differences emerge between only children and children with one or two brothers and/or sisters, particularly if higher educational levels are considered.

Similar results have been found for Italy (Dalla Zuanna, 2006) and for some developing countries during the fertility transition (see, for example, Knodel and Wongsith (1991) for Thailand, and Lloyd (1994) for comparative reviews). In order to explain the strong association between number of sons-daughters and levels of education in Thailand, researchers have built upon Blake's idea of a "dilution effect": the higher the number of siblings, the smaller the slice of resources available to each child. The statistical association was lower - although still clearly evident - during the transitional fertility decline in Vietnam (Anh et al., 1998). The authors believe that this result may be explained by the State's heavy subsidising of education, making parental resource constraints irrelevant in determining a child's schooling. In Thailand, on the other hand, the expense of children's education is mainly borne by their parents.

Although the above results are impressive, this kind of analysis has not been very popular among demographers: the number of studies conducted on the effect of parents' education on their own fertility is certainly higher than those concerning the effect of parents' fertility on the upward or downward mobility of children. The results presented above often result in a call for policies which oppose the negative association between family size and education (i.e. reducing school expenses for children with several siblings, or linking family allowances with parity for siblings), in order to allow all offspring similar opportunities. The aims of this kind of policy are principally egalitarian, but they may also increase fertility levels, as the responsibility of parents for the "quality" of their children in theory diminishes. Lastly, if parents reduce their fertility in order to improve the quality of their children, the above result has theoretical 
consequences, as it "proves" (ex-post) the rationality of couples' decisions. Indeed, in many contexts where birth control is widespread, the lower the fertility of parents, the more rapid the race to conquer the highest rungs of the social ladder on the part of the children.

Other important empirical evidence concerns Brazil and the black population of South Africa. Adopting a new-home economic approach, Lam (2003, p. 333) shows that "altruism in the family" prevails over "selfishness in the market place":

Until about eight years of schooling we do not see women responding to rising wages with significant increases in labour supply. The driving mechanism through which schooling reduces fertility, then, does not appear to be rising opportunity cost of time due to rising wages. Rather, couples respond to their increased productivity in producing child quality by reducing the number of children and investing more resources in each child.

With regard to comparisons of aspirations for upward mobility of parents to that for their children, as a possible motive for fertility decline, this result is very impressive. As far as I know, it is one of the few empirical comparisons that directly evaluates the two possible interpretations, and has data that shows that - in a number of contexts - status anxiety for children drives the first stage of fertility decline.

\subsection{An evolutionary viewpoint}

The term "status anxiety" - which Haaga (2001) mainly uses to refer to developing countries at the end of the $20^{\text {th }}$ century - was also used fourteen years earlier by Johansson (1987a, not quoted by Haaga) in order to describe the motivations of the European élite to reduce marital fertility beginning in the early $18^{\text {th }}$ century (see above). Haaga (p. 57) describes "status anxiety" as an ingrained characteristic of humans; its contemporary expression is explained by the evolution of social hierarchies among mammals over thousands of years:

Returning to humans, we are made very anxious by threats to our social position, and respond quickly to opportunities to advance our, or our children's, social position.

This view echoes the evolutionary explanation of fertility differences, which has recently become popular among scholars (Wachter and Bulatao, 2003; Aarssen, 2005). The main problem with this approach is the challenge of convincingly contextualizing transitional and post-transitional differential fertility and low-replacement fertility in an 
evolutionary perspective. If fertility is lower for the richest and most highly educated people and societies, the "golden rule" of evolution (i.e. the "fittest" individuals have more children who become parents) seems to be violated. This hurdle may be removed if the rule is partially changed: "the fittest individuals have better children who become parents". However, in those societies based on livestock and agriculture (but not all, as shown in the first part), larger may have overlapped with better, although this may have been only a "brief" moment in the history of humankind. Nowadays, we may be in the same situation as our hunter-gathering ancestors, as stated by Wachter (2003, p. 10) who summarizes the main points of a chapter by Kaplan and Lancaster (2003):

The modern concept of a quality-quantity trade-off in the demand for children has an analogy for hominid foragers. Compared with chimpanzees, hominids came to concentrate on an ecological food niche, including hunted prey and extracted nutrients, which demanded and rewarded skill and learning. Prolonged juvenile training and dependence, protracted parental investment, larger brains, and longer life-span are seen as coevolving, driven by returns to investment in "embodied capital". In this picture, evolution would have been equipping humans not so much with an instinct toward maximising total fertility as with instincts for adjusting familial resource transfers in response to the available lifetime returns to such investments.

This idea is also addressed by Lam (2003, p. 336) who, in the last part of the above-quoted chapter, compares evolutionary and economic approaches to fertility decline. In his discussion of "the evolutionary origin of indifference curves between quality and quantity of offspring," the author suggests that a quality-quantity trade-off in offspring is a highly plausible method of evolutionary adaptation. However, all of the above authors state that research on these topics is only in its infancy, and data supporting their hypotheses are controversial.

\section{Conclusions}

The principal idea put forth in this paper is as follows: it is possible to categorize the many interpretive frameworks employed by population scholars to explain fertility decline in modern societies into two groups. The first group includes those who point to the desire on the part of parents to improve their life conditions, while the second highlights the anxiety of parents for the future conditions of their children. As emphasized several times in this article, these two types of aspirations are not always easily distinguishable one from the other. They can easily coexist for the same person, or even the same social group, as often pointed out in observations of the decline in 
births over the first half of the $20^{\text {th }}$ century. Beginning with Dumont and his theory of social capillarity developed towards the end of the $19^{\text {th }}$ century, a number of authors have similarly suggested that the first phase of fertility decline in today's wealthy countries saw these two aspirations operate in tandem, dragging down both the number of desired children and those actually born.

That said, this distinction continues to hold considerable merit even today, as evidenced by the numerous authors who continue to refer (either implicitly or explicitly) to these two types of interpretive frameworks. In particular, those scholars who take inspiration from Ariès in order to explain the changes in reproductive behaviour that have occurred in post-modern societies (the so called Second Demographic Transition), suggest that the personal well-being aspirations of the two partners have gained the upper hand with respect to the those projected towards the child (i.e. a shift has occurred: from the child-king to the couple-queen). Understanding lowest-low fertility across the broad areas of southern Europe and Eastern Asia becomes difficult, however, without recognizing that in these regions the care and responsibility felt on the part parents for the social advancement of their own children is greater than that found in other wealthy countries.

As suggested by Becker, parents who are "altruistic in the family and selfish in the market place" are in an advantageous position to conquer the best places at life's banquet for their (few) children. This statement has been largely confirmed in developed and developing countries by the inverse relationship between number of siblings and achievement, expressed mainly in terms of education. These "Darwinian families," in competing with each other, closely resemble those families described by authors during the first half of the $20^{\text {th }}$ century, and by the fathers of demographic transition theory.

However, an important difference emerges when comparing the traditional picture of fertility decline with what has actually happened. Nowadays, in the rich world, fertility is higher where family ties between parents and children are weaker (as in Northern Europe and in the overseas English-speaking countries), where "new" types of marital behaviour (i.e. cohabitation, extramarital fertility and marriage disruption) are widespread, and where gender roles within couples and society are more balanced (see Billari and Kohler, 2004, for an extensive empirical overview). The idea - so widespread during the first half of the $20^{\text {th }}$ century, and incorporated into numerous formulations of transitional fertility decline theories (see e.g. Coale 1973, p. 54) - that the waning of the "traditional" family and fertility decline are closely intertwined, is negated by what has happened in developed countries over the last 20 years. A similar suggestion also comes from Cleland and Wilson's (1987, p. 27) review of the WFS data concerning developing countries: 
...the onset of demographic change [is not associated with the loss of] familial control of economic life.

Summarising, empirical findings do not confirm the idea that in either developed or developing worlds, the weaker the family, the lower the fertility. Conversely, where family ties between parents and children have traditionally been strongest, the mounting aspirations of parents for their children's quality may drive fertility far below replacement level. This emphasises the contrast which exists between parents' values and economic well-being and that of their children, particularly if the state (or other institutions) do not help parents to look after children's quality (Aassave et al., 2005). The same pattern may also occur in the near future in many developing countries. In other words, what has happened in southern Europe and most developed areas of eastern Asia may also occur in other places with strong family ties between parents and children. As suggested by Caldwell and Schindlmayr (p. 257):

...If the explanation provided by the Mediterranean, largely the Italian model, centered on patriarchy and the breadwinner, are correct, then the tendency to fall below replacement-level fertility as incomes rise will eventually occur throughout much of the rest of the world because patriarchy is widespread throughout Asia and Africa.

The idea that fertility behaviour is guided by competition between groups related by blood (i.e. parents and children), each vying for their children's upward mobility, does not fit very well with the notion that fertility is driven by competition, selfrealization, preferences, and/or the well-being of parents. The former idea inspired mainly the proponents of the SDT (Ariès, 1980; van de Kaa, 2004; Hakim, 2003; Kohler et al., 2005) in their efforts to explain fertility behaviour in post-modern societies today. But are these positions really in contrast to one another?

The SDT has now started to emerge in southern Europe and eastern Asia, where post-materialistic and post-modern values have become increasingly widespread. However, this is not necessarily in contrast to the value of children as "extensions" of their parents. Instead, the stress on blood ties may be seen differently, if the emphasis is placed on self-realization. Self-projection onto one's own child may easily be assumed to be an important driving motivation in post-modern society (van de Kaa, 2001). Moreover, this self-projection may be reinforced by weak "elective" family ties, i.e., those constructed on the basis of romantic love, cohabitation and marriage. The ties broken by a marital disruption (which is also rapidly spreading in many countries characterised by strong family ties, such as Italy, Spain, Japan, and South Korea) may be replaced by an additional emphasis placed on blood ties, i.e., connections between parents and children. 
Although the post-modern desire for one (or more) child/ren may co-exist with other post-modern values and aspirations, they may also be in opposition, particularly where the blood family ties are strong, and public institutions leave child-rearing primarily to parents, due in part to widespread rhetoric concerning the strength and importance of the family.

\section{Acknowledgements}

A first draft of this paper was written during a fellowship in July and August 2004 at the Research School of Social Sciences, Australian National University of Canberra (Australia), granted by the Demography and Sociology Program. A preliminary version was discussed during the workshops "Family in lowest-low fertility contexts" (Institute for Social Development and Policy Research, Seoul, South Korea, 17 August 2005) and "Generations. Family ties between past and present" (Department of History, University of Pisa, Italy, 30 September 2005). I would like to thank Francesco Billari, Peter McDonald, Keong-Sok Park, Chris Wilson, all participants in the above-mentioned workshops, and the anonymous referees of Demographic Research for their useful comments. 


\section{References}

Aarssen L.W. (2005) "Why is fertility lower in wealthier countries? The role of relaxed fertility-selection", Population and Development Review, 31, 1, 113-126.

Aassve A., S. Mazzuco and L. Mencarini (2005) "Childbearing and well-being: a comparative analysis of European welfare regimes", Journal of European Social Policy, 15, 283-299.

Anh T.S., J. Knodel, D. Lam and J. Friedman (1998) "Family size and children education in Vietnam", Demography, 35, 1, 57-70.

Ariès P. (1980) "Two successive motivations for the declining birth rate in the West", Population and Development Review, 6, 4, 645-650.

Becker G. (1981) "Altruism in the family and selfishness in the market place", Economica, New Series, 48, 189, 1-15.

Berent J. (1952) "Fertility and social mobility", Population Studies, 5, 3, 244-260.

Bettio F. and P. Villa (1998) "A Mediterranean perspective on the breakdown of the relationship between job participation and fertility", Cambridge Journal of Economy, 22, 137-171.

Billari F. and H.-P. Kohler (2004) "Pattern of low and lowest-low fertility in Europe", Population Studies, 58, 2, 161-176.

Blake J. (1985) "Number of siblings and social mobility", American Sociological Review, 50, 84-94.

Blake J. (1989) Family Size and Achievement, University of California Press, Berkeley, USA.

Bresard M. (1950) "Mobilité sociale et dimension de la famille", Population, 5, 3, 211566.

Caldwell J. and T. Schindlmayr (2003) "Explanations of the fertility crisis in modern societies: a search for commonalities", Population Studies, 57, 3, 241-263.

Caldwell J.C. (1982) Theory of Fertility Decline, Academic Press, London.

Caldwell J.C. (2004) "Demographic theory: a long view", Population and Development Review, 30, 2, 297-316.

Caldwell J.C. (2005) "On net intergenerational wealth flows: an update", Population and Development Review, 31, 4, 721-740.

Carr-Saunders A. (1936) World Population, Oxford University Press, Oxford, UK.

Casterline J. (2001) "The pace of fertility transition: national patterns in the second half of the twentieth century", in R. Bulatao and J. Casterline (eds.) Global Fertility 
Transition, a supplement to vol. 27 of Population and Development Review, 1752.

Cleland J. and C. Wilson (1987) "Demand theories of fertility decline: an iconoclastic view", Population Studies, 41, 5-30.

Coale A. (1973) "The demographic transition reconsidered", in IUSSP, International Population Conference of Liege, vol. 1, 53-72.

Dalla Zuanna G. (2001) "The banquet of Aeolus: a familistic interpretation of Italy's lowest low fertility", Demographic Research, 4, 5, 133-162.

Dalla Zuanna G. (2004) "The small number of children in the strong family. Values and low fertility in Italy", Genus, 1, 39-70.

Dalla Zuanna G. (2006) "Population replacement, social mobility and development in Italy during the $20^{\text {th }}$ century", Journal of Modern Italian Studies, 11, 2, 188-208.

Dalla Zuanna G. and G. Micheli (2004), editors, Strong Family and Low Fertility: A Paradox?, Kluwer Academic Publishers, The Netherlands.

Davis K. (1937) [1997] "Reproductive institutions and the pressure for population", Sociological Review, July 289-306, reprinted in Population and Development Review, 23, 3, 611-624.

Davis K. (1963) "The theory of change and response in modern demographic history, Population Index, 29, 4, 345-366.

Esping-Andersen G. (2007) (ed.) Family Formation and Family Dilemmas in Contemporary Europe, BBVA Foundation, Bilbao, Spain.

Esping-Andersen G., M. Guell, S. Brodmann (2007) "When mothers work and fathers care. Household fertility decisions in Denmark and Spain", in G. EspingAndersen (ed.) Family Formation and Family Dilemmas in Contemporary Europe, 129-154, BBVA Foundation, Bilbao, Spain.

Flandrin J. (1976) Families in the Former Times, Cambridge University Press, Cambridge, UK.

Girard A. (1951) "Mobilité sociale et dimension de la famille. Deuxième Partie: enquête dans les lycées et les facultés", Population, 6, 1, 103-124.

Glass D. (1965) "Population growth and population policy", in M. Sheps and J. Ridley (eds.): Public Health and Population Change, University of Pittsburgh Press, USA.

Greenhalgh S. (1988) "Fertility as mobility: Sinic transition", Population and Development Review, 14, 4, 629-674. 
Haaga J. (2001) "Comment: the pace of fertility decline and the utility of evolutionary approaches", in R. Bulatao and J. Casterline (eds.) Global Fertility Transition, a supplement to vol. 27 of Population and Development Review, 53-59.

Hakim C. (2000) Work-Lifestyle Choices in the 21st Century: Preference Theory, Oxford, Oxford University Press.

Hakim C. (2003) "A new approach to explaining fertility patterns: preference theories", Population and Development Review, 29, 3, 349-374.

Hoem, J.M. (2005) "Why does Sweden have such high fertility?" Demographic Research, 13, 22, 559-572.

Inglehart R. (1977) Silent Revolution: Changing Values and Political Styles Among Western Publics, Princeton University Press, Princeton, USA.

Johansson S. (1987a) "Status anxiety and demographic contraction of privileged populations", Population and Development Review, 13, 3, 439-470.

Johansson S. (1987b) "Centuries of childhood / centuries of parenting: Philippe Ariès and the modernisation of privileged infancy", Journal of Family History, 12, 343-365.

Johansson S. (1997) "Fertility and family history: using the past to explain the present", Population and Development Review, 23, 3, 627-637.

Kaplan H.S. and J.B. Lancaster (2003) "An evolutionary and ecological analysis of human fertility, mating patterns, and parental investment", in K.W. Wachter and R. Bulatao (eds.) Offspring. Human Fertility Behaviour in Biodemographic Perspective, the National Academic Press, Washington, DC, USA, 170-223.

Knodel J. and M. Wongsith (1991) "Family size and children education in Thailand: evidence from a national sample", Demography, 28, 1, 119-131.

Knodel J., N. Havanon and W. Sittitrai (1990) "Family size and education of children in the context of rapid fertility decline", Population and Development Review, 16, $1,31-62$.

Kohler H.-P. and J.L. Rodgers (2003) "Education, fertility, and heritability: explaining a paradox", in K.W. Wachter and R. Bulatao (eds.), Offspring. Human Fertility Behaviour in Biodemographic Perspective, the National Academic Press, Washington, DC, USA, 46-90.

Kohler H.-P., J.L. Rodgers and K. Christensen (1999) "Is fertility behaviour in our genes? Findings from a Danish twin study", Population and Development Review, 25, 253-288. 
Kohler H.-P., J.R. Behrman and A. Skythe (2005) "Partner + Children = Happiness? The effects of partnerships and fertility on well-being", Population and Development Review, 31, 3, 407-445.

Lam D. (2003) "Evolutionary biology and rational choice in models of fertility", in K.W. Wachter and R. Bulatao (editors), Offspring. Human Fertility Behaviour in Biodemographic Perspective, the National Academic Press, Washington, DC, USA, 322-338.

Lindert P.H. (1980) "Child costs and economic development", in R.A. Easterlin (ed.): Population and Economic Change in Developing Countries, University of Chicago Press, Chicago, USA, 4-79.

Livi Bacci M. (2001) "Too few children and too much family”, Daedalus, 3, 139-156.

Lloyd C. (1994) "Investing in the next generation: the implications of high fertility at the level of the family, in R. Cassen (ed.): Population and Development: Old Debates, New Conclusions, New Brunswick, NJ, USA, 181-202.

Lorimer F. and F. Osborn (1934) Dynamics of Population, The MacMillan Company, New York, USA.

Mason K. (1997) "Explaining fertility transition”, Demography, 34, 4, 443-454.

McDonald P. (2000) "Gender equity in theory of fertility transition", Population and Development Review, 26, 427-439.

McNicoll G. (2001) "Government and fertility in transitional and post-transitional societies", in R. Bulatao and J. Casterline (eds.) Global Fertility Transition, a supplement to vol. 27 of Population and Development Review, 129-159.

Micheli G. (2000) "Kinship, family, and social network: the anthropological embedment of fertility change in Southern Europe", Demographic Research, 3, 13.

Notestein F. (1945) "Population, the long view", in T. Schultz (ed.): Food for the World, Chicago University Press, Chicago, USA.

Palomba R. (1995) "Italy, the invisible change", in R. Palomba and H. Moors (eds.) Population, Family and Welfare, 158-176, The Clarendon Press, Oxford, UK.

Reher D. (1998) "Family ties in Western countries: persistent contrasts", Population and Development Review, 24, 2, 203-234.

Schneider P. and J. Schneider (1996) Festival of the Poor: Fertility Decline and the Ideology of Class in Sicily, 1860-1980, University of Arizona Press, Tucson, AR, USA.

Smith R.M. (1984), editor, Land, Kinship, and Life-Cycle, CUP, Cambridge, UK. 
Thompson W. and D. Lewis (1964) Population Problems (5 ${ }^{\text {th }}$ edition), McGraw-Hill, New York, USA.

Udry J.R. (1994) "The nature of gender", Demography, 31, 4, 561-573.

van de Kaa D. (1996) "Anchored narratives: the story and findings of half a century of research into the determinants of fertility", Population Studies, 50, 389-432.

van de Kaa D. (2001) "Post-modern fertility preferences: from changing value orientation to new behaviours", in R. Bulatao and J. Casterline (eds.) Global Fertility Transition, a supplement to vol. 27 of Population and Development Review, 290-331.

van de Kaa D. (2004) "The true commonality: in reflexive modern societies fertility is a derivative", Population Studies, 58, 1, 77-92.

Wachter K.W. (2003) "Biodemography of fertility and family formation", in K.W. Wachter and R. Bulatao (eds.), Offspring. Human Fertility Behaviour in Biodemographic Perspective, the National Academic Press, Washington, DC, USA, 1-17.

Wachter K.W. and R. Bulatao (2003), (eds.), Offspring. Human Fertility Behaviour in Biodemographic Perspective, the National Academic Press, Washington, DC, USA.

Westoff C.F. (1953) "The changing focus of differential fertility research: the social mobility hypothesis", The Milbank Memorial Fund Quarterly, 31, 1, 24-38.

Westoff C.F. (1981) "Another look at fertility and social mobility”, Population Studies, $35,1,132-135$.

Westoff C.F., R.G. Potter Jr and P.C. Sagi (1963) The Third Child: A Study in Prediction of Fertility, Princeton University Press, Princeton, USA.

Westoff C.F., R.G. Potter Jr, P.C. Sagi and E. Mishler (1961) Family Growth in Metropolitan America, Princeton University Press, Princeton, USA.

Zimmer B.G. (1981) "The impact of social mobility on fertility: a reconsideration", Population Studies, 35, 1, 120-131. 